УДК 343.8

DOI https://doi.org/10.32844/2618-1258.2019.3-2.20

КВЯТКІВСЬКИЙ Ю.В.

\title{
КРИМІНАЛЬНО-ВИКОНАВЧА ХАРАКТЕРИСТИКА ОСІБ, ЯКІ ВІДБУВАЮТЬ ПОКАРАННЯ НА ТИМЧАСОВО ОКУПОВАНИХ ТЕРИТОРІЯХ ДОНЕЦЬКОЇ ТА ЛУГАНСЬКОЇ ОБЛАСТЕЙ
}

У статті здійснено кримінально-виконавчу характеристику осіб, які відбувають покарання на тимчасово окупованих територіях Донецької та Луганської областей. Надано авторське визначення вказаної правової категорії. Проаналізовано зміст особливостей досліджуваного правового явища. 3'ясовано, що кримінально-виконавча характеристика осіб, які відбувають покарання на тимчасово окупованих територіях Донецької та Луганської областей, відрізняється від кримінально-виконавчої характеристики будь-яких інших ув'язнених. У вітчизняній науці сформовано стабільні підходи до розуміння сутності кримінально-виконавчої характеристики особи, а також до того, які елементи ії складають. Визначено, що специфіка кримінально-виконавчих установ на тимчасово окупованих територіях Донецької та Луганської областей, у яких відбувають покарання засуджені, полягає в такому: під контроль окупаційної адміністрації перейшла більшість установ виконання покарань на території Донецької та Луганської областей; частина персоналу залишилась працювати на окупантів, інші вакансії зайняли особи із числа прихильників незаконних збройних формувань; у нової адміністрації пенітенціарних закладів сформована чітка антиукраїнська позиція, яка проявляється у жорстокому ставленні до засуджених; зафіксовано низку порушень прав ув'язнених, що проявляється в тому числі й у забороні переведення на підконтрольні Україні території, побиттях, катуваннях, участі у тренуваннях російського спецназу. Зроблено висновок, що особи, які відбувають покарання на тимчасово окупованих територіях Донецької та Луганської областей, є безпосередньо залежними від умов, в яких вони відбувають покарання, а також тих умов, які забезпечує окупаційна адміністрація установ виконання покарань на непідконтрольних територіях. Із даного приводу варто зробити висновок про те, що ув'язнені перебувають у важких умовах, а їхні права порушуються в різноманітні способи. Наступним виділеним нами елементом характеристики є правовий статус таких осіб. Специфіка правового статусу ув'язнених на тимчасово окупованих територіях Донецької та Луганської областей зумовлена тим, що він $є$ неоднорідним для осіб, які перебувають в ув'язненні.

Ключові слова: кримінально-виконавча характеристика, законодавче регулювання, виконання покарання, тимчасово окуповані території Донеиької та Луганської областей, засуджений.

In the article the criminal-executive description of persons serving sentences in the temporarily occupied territories of Donetsk and Luhansk regions is explored. Author's definition of the specified legal category is given. The content of the features of the investigated legal phenomenon is analyzed. It is found that the criminal characteristics of persons serving sentences in the temporarily occupied territories of Donetsk and Luhansk oblasts are different from the criminal characteristics of any other prisoners. In national science, stable approaches to understanding the nature of criminal characteristics of a person, as well as to what elements of it are formed. It is determined that the specifics of the penal institutions in the temporarily occupied territories of Donetsk and Lugansk regions where the prisoners are serving their sentences are as follows: most of the penal institutions in the territory of Donetsk and Luhansk oblasts have come under the control of the occupation administration; some of the staff remained to work for the invaders,

(C) КВЯТКІВСьКИЙ Ю.В. - прокурор (Прокуратура Львівської області) 
other vacancies were occupied by persons among the supporters of illegal armed groups; the new administration of penitentiary institutions has formed a clear anti-Ukrainian position, which manifests itself in the cruel treatment of prisoners; a number of violations of prisoners' rights were recorded, which is also reflected in the prohibition of transfer to the territories controlled by Ukraine, beatings, torture, participation in training of the Russian special forces. It is concluded that persons serving sentences in the temporarily occupied territories of Donetsk and Lugansk regions are directly dependent on the conditions in which they are serving their sentences, as well as the conditions provided by the occupation administration of penal institutions in uncontrolled territories. For this reason, it should be concluded that prisoners are in difficult conditions and their rights are violated in various ways. The next feature we have highlighted is the legal status of such individuals. The specifics of the legal status of detainees in the temporarily occupied territories of Donetsk and Luhansk oblasts are due to the fact that it is not uniform for the detained persons.

Key words: criminal-executive characteristic, legislative regulation, execution of punishment, temporarily occupied territories of Donetsk and Luhansk region, convicted.

Вступ. Удосконалення порядку умов виконання та відбування кримінальних покарань $є$ необхідною складовою частиною для розбудови України як демократичної, правової держави. Чинне кримінально-виконавче законодавство України грунтується на принциповому положенні, згідно 3 яким засуджена особа є не об'єктом виховного впливу, а суб'єктом кримінально-виконавчих відносин, захист прав, законних інтересів та обов'язків яких має гарантувати кримінально-виконавче законодавство. Отже, для здійснення кримінально-виконавчої характеристики виконання покарання важливим $є$ визначення дієвості та ефективності зворотного зв'язку між державними установами, що виконують покарання, та особою засудженого з точки зору досягнення мети виправлення та повернення в суспільство законослухняної особи. Дане питання актуалізується в умовах перебування засуджених на тимчасово окупованих територіях Донецької та Луганської областей, адже зворотний зв'язок між державними установами, що виконують покарання, та особою засудженого ускладнюється участю у кримінально-виконавчих правовідносинах окупаційної адміністрації. Саме тому, як нами вже неодноразово зазначалось в даній роботі, замість виправлення та повернення в суспільство законослухняної особи на окупованих територіях відбувається використання особи засудженого у своїх інтересах та порушення їх усіх можливих прав.

Сучасна наука кримінально-виконавчого права має спрямовувати зусилля на дослідження особи, яка засуджена до ув'язнення. В умовах, коли така особа перебуває поза контролем держави, дане питання актуалізується ще більше. Тому, враховуючи, що завданням даної науки є пошук оптимальних шляхів удосконалення правового регулювання діяльності органів і установ виконання покарань, вивчення особи засудженого, розроблення із цією метою відповідних теоретичних і практичних рекомендацій у рамках нашого дослідження виникає необхідність надати кримінально-виконавчу характеристику осіб, які відбувають покарання на тимчасово окупованих територіях Донецької та Луганської областей, тобто більш поглиблено вивчити правовий статус особистості засудженого і ті проблеми, із якими він стикається у процесі ув'язнення на непідконтрольній Україні території.

Стан дослідження. Загалом, питання кримінально-виконавчої характеристики засуджених у вітчизняній науці досліджувалось кількома науковцями, серед яких ми відзначимо таких, як: І.Г. Богатирьов, С.Я. Бурда, Г.В. Житник, Т.К. Лобжина, С.В. Царюк. Разом із тим жоден із наведених дослідників не розкривав кримінально-виконавчу характеристику осіб, які відбувають покарання на тимчасово окупованих територіях Донецької та Луганської областей, оскільки вони зосереджували свою наукову увагу на більш загальних питаннях. У свою чергу, окремі аспекти правового статусу засуджених, які відбувають покарання на тимчасово окупованих територіях Донецької та Луганської областей, встановлювали такі дослідники, як: О.П. Букалов, Д.Л. Денисенко, С.Ю. Захаров, В.В. Карелін, Н.М. Мельник, В.О. Новіков, В.М. Янко. Проте у їхніх працях досліджувались лише окремі особливості дотримання прав та свобод засуджених на окупованих територіях, що не можна віднести до повноцінного кримінально-виконавчого аналізу. Саме тому здійснення такого дослідження є важливим для досягнення мети та завдань нашої роботи.

Результати дослідження. Так, І.Г. Богатирьов визначає поняття кримінально-виконавчої характеристики як впорядкований чинним законодавством порядок умов виконання та відбування 
кримінальних покарань. Вчений зазначає, що вивчення особистості засудженого протягом періоду відбування покарання повинне охоплювати всі без винятку елементи характеристик засудженого, а саме містити соціально-демографічні, кримінально-правові, психолого-педагогічні, реабілітаційні ознаки, тривати в часі та сприяти полегшенню адаптації в період звільнення $[1$, с. 54]. Із такого визначення можна зробити висновок, що кримінально-виконавчою характеристикою покарання $\epsilon$ певна аналітико-пізнавальна діяльність, що здійснюється з метою всебічного вивчення порядку та умов виконання й відбування кримінальних покарань. Щодо виділених елементів характеристики засудженої особи, то звернемо увагу на те, що вони розкривають специфіку його особистості та ступінь його виправлення. Кримінально-виконавча характеристика осіб, які відбувають покарання на тимчасово окупованих територіях Донецької та Луганської областей, через призму такого підходу, на нашу думку, має включати інші елементи. У першу чергу, на кримінально-виконавчу характеристику таких осіб безпосередньо впливає місце відбування покарання засудженою особою. Також, на наше переконання, здійснюючи кримінально-виконавчу характеристику осіб, які відбувають покарання на тимчасово окупованих територіях Донецької та Луганської областей, варто враховувати їхній правовий статус, тобто їхнє становище у відносинах із окупаційною адміністрацією та сукупність прав і обов'язків, якими вони наділяються нею.

Т.К. Лобжина розглядає кримінально-виконавчу характеристику у широкому та у вузькому значенні. У широкому значенні кримінально-виконавча характеристика з точки зору дослідниці охоплює всі сфери життя людини, засудженої під час відбування покарання: показує де, в якій кримінально-виконавчій установі вона відбуває покарання; містить дані щодо дотримання нею порядку та умов відбування покарання, ставлення до праці, участі в самодіяльних організаціях, підвищення свого загальноосвітнього та професійного рівня, інтенсивності погашення заборгованості за виконавчими листами, підтримання зв'язків із сім'єю, рідними та знайомими, ефективності використання спеціальних прав на побачення, отримання посилок (передач), ставлення до вчиненого злочину, планування свого життя на майбутнє тощо. У вузькому розумінні кримінально-виконавча характеристика розкривається як відтворення дисциплінарної практики, що застосовувалася до конкретного засудженого, і практично є не лише засобом забезпечення режиму відбування покарання, а й результатом у певному розумінні виправного впливу на конкретну засуджену особу [2, с. 144]. Іншими словами, попередньо проаналізований підхід, автором якого $\epsilon$ І.Г. Богатирьов, $є$ широким підходом до розуміння сутності кримінально-виконавчої характеристики. Разом із тим Т.К. Лобжина, на нашу думку, значно досконаліше розкриває елементи кримінально-виконавчої характеристики: вони пов'язані як із установою, у якій відбуває покарання засуджений (установа, умови тощо), так і з його персоною (права та обов'язки, особистість тощо). У контексті тематики нашого дослідження такий підхід є більш досконалим, оскільки в його основі - саме ті елементи, які зумовлюють специфіку відбування покарання на тимчасово окупованих територіях Донецької та Луганської областей. Так, кримінально-виконавчі установи в даному контексті відрізняються тим, що вони були окуповані разом із в'язнями і в них встановлено окупаційну адміністрацію; умови відбування покарання є незадовільними, має місце неналежне забезпечення базових потреб засуджених та їхньої експлуатація; такі особи позбавлені можливості підтримувати зв'язки із сім'єю, рідними та знайомими; таким особам проблематично перевестись до іншої установи відбування покарання на підконтрольну Україні територію. Тобто, як можна переконатись, широкий підхід Т.К. Лобжиної дійсно зручно застосовувати для здійснення кримінально-виконавчої характеристики осіб, які відбувають покарання на тимчасово окупованих територіях Донецької та Луганської областей. Щодо вузького підходу, сформульованого вченою, то він полягає в аналізі особи конкретного засудженого, тобто така концепція не належить до предмету нашого дослідження.

С.Я. Бурда визначив кримінально-виконавчу характеристику як виправно-реабілітаційну характеристику засудженої особи під час відбування покарання, що водночас $є$ підставою для визначення ступеня іії виправлення, матеріальною підставою для зміни обсягу кримінальної репресії під час відбування покарання, надає можливість адміністрації установи поліпшити умови утримання засудженої особи упродовж певного часу, визначеного законом [3, с. 219]. На відміну від І.Г. Богатирьова, С.Я. Бурда розглянув кримінально-виконавчу характеристику у виключно вузькому аспекті. «Виправно-реабілітаційна характеристика» означає аналіз конкретної засудженої особи на предмет ії̈ виправлення та готовності адаптуватись до законослухняного життя у суспільстві. Кримінально-виконавча характеристика у вузькому розумінні здійснюється в тому числі й для поліпшення умов відбування покарання засуджених. Тож у даному контексті наведений підхід С.Я. Бурди не є вдалим для нашого дослідження. 
С.В. Царюк у своїй праці досліджував питання кримінально-виконавчої характеристики засуджених, які відбувають покарання у виправних колоніях максимального рівня безпеки, тож визначив іï як врегульоване чинним кримінально-виконавчим законодавством, передбачене у часі комплексне вивчення особи, яка відбуває покарання у виправній колонії максимального рівня безпеки, завдяки чому забезпечується вибір та застосування засобів виправлення і ресоціалізації засудженого та його адаптація після звільнення. Дослідник, як і Т.К. Лобжина, розглядає кримінально-виконавчу характеристику у двох значеннях: широкому - для визначення процесу виконання-відбування будь-якого виду кримінального покарання, та вузькому - вивчення порядку та умов відбування покарання у виправних колоніях максимального рівня безпеки. Визначено, що складовими елементами (ознаками) запропонованої характеристики є такі: соціально-демографічні, соціально-психологічні ознаки; правовий статус; умови відбування покарання та ступінь виправлення засуджених, які відбувають покарання у виправних колоніях максимального рівня безпеки $[4$, с. 10]. Вузький та широкий підходи дослідника відрізняються від ідентичних за назвою концепцій інших науковців. У контексті нашого дослідження, слідуючи такій моделі, кримінально-виконавча характеристика осіб, які відбувають покарання на тимчасово окупованих територіях Донецької та Луганської областей, є вузьким підходом, а кримінально-виконавча характеристика осіб, які відбувають покарання, - широким.

Тож на основі здійсненого дослідження зробимо висновок про те, що кримінально-виконавча характеристика осіб, які відбувають покарання на тимчасово окупованих територіях Донецької та Луганської областей, - це вивчення специфіки відбування покарання засудженими особами, яка охоплює всі сфери їхнього життя протягом періоду перебування в пенітенціарних установах: в якій кримінально-виконавчій установі вона відбуває покарання; яким $є$ правовий статус таких осіб та умов відбування покарання; наскільки ефективними $є$ використання ним прав та свобод.

Так, із встановленого нами слідує, що кримінально-виконавчу характеристику осіб, які відбувають покарання на тимчасово окупованих територіях Донецької та Луганської областей, варто розглядати в контексті трьох її елементів, таких як:

1) специфіка кримінально-виконавчих установ на тимчасово окупованих територіях Донецької та Луганської областей, у яких відбувають покарання засуджені;

2) специфіка правового статусу осіб, які відбувають покарання на тимчасово окупованих територіях Донецької та Луганської областей;

3) можливості реалізації прав і свобод особами, які відбувають покарання на тимчасово окупованих територіях Донецької та Луганської областей.

Так, питання кримінально-виконавчих установ на тимчасово окупованих територіях Донецької та Луганської областей, у яких відбувають покарання засуджені, уже частково розглядалось нами в даній роботі. Унаслідок окупації під контроль бойовиків перейшли 15 з 16 установ виконання покарань у межах Луганської області (Брянська ВК № 11, Алчевська ВК № 13, Перевальська ВК № 15, Краснолуцька ВК № 19, Комісарівська ВК № 22, Чорнухінська ВК № 23, Петровська ВК № 24, Суходільська ВК № 36, Свердловська ВК № 38, Слов’яносербська ВК № 60, Селезнівська ВК № 143, Луганський ВЦ № 134, Штерівський ВЦ № 137, Луганська УВП № 17) та 14 із 20 установ виконання покарань Донецької області. (Жданівська ВК № 3, Калинівська ВК № 27, Торезька ВК № 28, Кіровська ВК № 33, Макіївська ВК № 32, Снакіївська ВК № 52, Мічуринська ВК № 87, Микитинська ВК № 87, Західна ВК № 97, Волноваська ВК № 120, Донецька ВК № 124, Сніжинська ВК № 127, Киселівский ВЦ № 125, Донецька УВП № 5) [5, с. 7]. Тобто більша частина установ відбування покарань, які розміщуються в межах Донецької та Луганської областей, сьогодні перебувають під контролем окупантів. Відповідно, і більшість осіб, які станом на 2014 рік відбували покарання в установах виконання покарання на територіях Донецької та Луганської областей, залишились на окупованих територіях. Як свідчать дані, наведені у Вісімнадцятій доповіді УВКПЛ щодо ситуації із правами людини в Україні, кількість ув'язнених на цих територіях станом на початок війни становила приблизно 9500 осіб [6, с. 15]. Саме тому місце відбування покарання $є$ важливим елементом їхньої кримінально-виконавчої характеристики.

Специфіка установ виконання покарань на окупованих територіях вже досліджувалась нами в рамках даної роботи. Зокрема, нами було встановлено, що ії становить дві групи особливостей: особливості, пов'язані з персоналом установ виконання покарань, та особливості, пов'язані із забезпеченням прав засуджених. На нашу думку, схожим чином варто охарактеризувати і специфіку кримінально-виконавчих установ на тимчасово окупованих територіях Донецької та Луганської областей, у яких відбувають покарання засуджені, як складову частину криміналь- 
но-виконавчої характеристики осіб, які відбувають покарання на тимчасово окупованих територіях Донецької та Луганської областей, адже, як свідчить аналіз наукової літератури, саме персонал $є$ тією визначальною відмінністю, через яку умови відбування покарання на окупованих територіях відрізняються від умов відбування покарання на підконтрольній Україні території.

Першою особливістю $є$ те, що в рамках захоплення територій в установах виконання покарань також було встановлено окупаційне управління. Було створено «Міністерство внутрішніх справ Донецької народної республіки» та «Міністерство внутрішніх справ Луганської народної республіки», які взяли на себе обов' язки щодо забезпечення виконання покарань, утримання під вартою підозрюваних, обвинувачених та засуджених, а також інші функції Державної кримінально-виконавчої служби України. Як вже зазначалось нами в даній роботі, значна частина персоналу закладів виконання покарання звільнилася, проте низка працівників залишилися та перейшли на бік незаконних збройних формувань. Логічно, що багато з тих працівників, які залишились, симпатизували незаконним воєнізованим угрупуванням, тому за проукраїнську позицію до засуджених застосовувалися утиски ще до того, як установи перейшли під ефективний контроль членів незаконних збройних формувань. Із перших днів окупації окупанти приймали участь разом $з$ адміністрацією в нелюдському або грубому ставленні до ув'язнених, застосуванні непередбачених чинним законодавством видів покарання та примушенні до виконання робіт. Також відбувалось залякування в'язнів із застосуванням спеціальних засобів (світлошумових гранат) та зброї [7, с. 29]. Існує низка інших свідчень про порушення прав ув'язнених зі сторони окупаційної адміністрації. Так, наприклад, низка джерел вказує на те, що адміністрація установ виконання покарань категорично відмовляла засудженим у переведенні на підконтрольну Україні території. Окрім того, повідомлялось про те, що на окупованих територіях Донецької та Луганської областей на ув'язнених «тренувався» російський спецназ [8]. Таким чином, із огляду на зазначене зробимо висновок про те, що специфіка кримінально-виконавчих установ на тимчасово окупованих територіях Донецької та Луганської областей, у яких відбувають покарання засуджені, полягає в тому, що:

1) під контроль окупаційної адміністрації перейшла більшість установ виконання покарань на території Донецької та Луганської областей;

2) частина персоналу залишилась працювати на окупантів, інші вакансії зайняли особи із числа прихильників незаконних збройних формувань;

3) у нової адміністрації пенітенціарних закладів сформована чітка антиукраїнська позиція, яка проявляється в жорстокому ставленні до засуджених;

4) зафіксовано низку порушень прав ув'язнених, що проявляється в тому числі й у забороні переведення на підконтрольні Україні території, побиттях, катуваннях, участі у тренуваннях російського спецназу.

Наступним елементом кримінально-виконавчої характеристики осіб, які відбувають покарання на тимчасово окупованих територіях Донецької та Луганської областей, на нашу думку, $є$ встановлення специфіки правового статусу осіб, які відбувають покарання на тимчасово окупованих територіях Донецької та Луганської областей.

Так, специфіка правового статусу осіб, які відбувають покарання на тимчасово окупованих територіях Донецької та Луганської областей, передусім зумовлена тим, що тримання під вартою осіб на непідконтрольній уряду території є незаконним. Проте відсутність підстав для тримання під вартою за законодавством України не є перешкодою для окупаційної влади, тобто особи, засуджені судами України до початку окупації, продовжують відбувати покарання на непідконтрольній уряду території. І при цьому, як нами неодноразово відзначалось, їхнє переведення на підконтрольні території є суттєво ускладненим. Так само особи, які мали статус підозрюваних, підсудних, але ще не були засуджені і трималися під вартою станом на початок окупації, теж знаходяться в місцях позбавлення волі на окупованих територіях. Тому сьогодні Україна може лише опосередковано впливати на тримання осіб у місцях позбавлення волі на непідконтрольній уряду території, а також вести переговори з окупантами на предмет переведення таких осіб до пенітенціарних закладів на підконтрольну територію.

Автори доповіді «Права позбавлених волі, які утримуються під вартою в ОРДЛО» виділяють групи осіб, які тримаються під вартою на непідконтрольній території:

1) ті, що були засуджені і вирок щодо яких вступив у законну силу до початку антитерористичної операції;

2) ті, що були засуджені, але вирок щодо яких не вступив у законну силу до початку антитерористичної операції; 
3) ті, що не були засуджені, але справа яких знаходилася у суді першої інстанції;

4) ті, щодо кого проводилося досудове розслідування на момент початку антитерористичної операції;

5) ті, що були затримані та/або засуджені членами незаконних збройних формувань [5, с. 29].

На нашу думку, кожну з перерахованих груп варто розглядати в контексті особливостей їхнього правового статусу. Так, для першої групи осіб, у яких вирок набрав законної сили, особливо актуальні питання зарахування строку тримання під вартою на непідконтрольній уряду території до строків відбування покарання, а також застосування до них так званого «Закону Савченко», умовно-дострокового звільнення, амністії. 3 іншого боку, це найменш вразлива категорія засуджених. Вони вже були засуджені, і хоча були спроби перегляду вироків щодо них, загалом вони продовжують відбувати покарання, встановлені українськими судами. Так само у зв'язку із тим, що особи, які належать до цієї групи, вже відбували покарання станом на початок війни, існує висока вірогідність того, що вони все ж вийдуть на волю в ті строки, які були встановлені вироком щодо них.

Особливої уваги потребують засуджені до довічного позбавлення волі. Нерідко вони чують погрози переглянути їх вироки. А оскільки так званий «Кримінальний кодекс Донецької народної республіки» встановлює можливість застосування смертної кари за окремі тяжкі злочини, життя цих засуджених може в будь-яких момент опинитися в безпосередній небезпеці.

Інші чотири групи тією чи іншою мірою залежать від квазісудових органів невизнаних республік. Оскільки під час евакуації українські суди залишили в непідконтрольних уряду регіонах матеріали справ, незаконні збройні формування змогли заволодіти документами і продовжити свій квазісудовий розгляд. Тільки в деяких судах Луганської області під час евакуації співробітники спалили матеріали кримінальних і цивільних справ, які перебували на розгляді. У деяких випадках справи затриманих та обвинувачених перебувають на підконтрольній уряду території, а самі вони - на непідконтрольній. У таких випадках квазісуди відновили матеріали проваджень за власним розсудом, аби тільки розглянути справи. Зафіксовано випадки, коли процес розгляду справи відбувався за відсутності свідків, або, в іншому випадку, підозрюваному пропонувалося визнати повністю свою провину, щоб мати шанс вийти на волю, бо час, який він провів під вартою, вже перебільшував строк покарання, передбачений за злочин, який йому інкримінувався.

За думкою членів незаконних збройних формувань, усі засуджені, обвинувачені, підозрювані незалежно від стадії розгляду їхньої справи знаходяться під їхньою юрисдикцією. Тих, хто походить із Донецької чи Луганської областей, взагалі називають «громадянами» невизнаних республік та пропонують отримати місцевий «паспорт». Українські паспорти адміністрація установ виконання покарань зазвичай «губить», аби здійснювати психологічний тиск на засуджених, погрожуючи їм. Статус таких осіб за українським законодавством не визначений. Тому спільна проблема усіх груп осіб, що перебувають під вартою на непідконтрольній уряду території, - неврегульованість правового статусу. Іншими словами, правовий статус осіб, які відбувають покарання на тимчасово окупованих територіях Донецької та Луганської областей, залежить від того, чи вирок вступив у законну силу до початку антитерористичної операції, чи такі особи були затримані та/або засуджені членами незаконних збройних формувань, проте у цілому він не $є$ урегульованим взагалі. Тому це, з одного боку, надає можливості окупаційної адміністрації використовувати в'язнів у своїх інтересах, а з іншого - не породжує жодні додаткові гарантії на підконтрольній Україні території.

Таким чином, на підставі вищезазначеного зробимо висновок про те, що специфіка правового статусу осіб, які відбувають покарання на тимчасово окупованих територіях Донецької та Луганської областей, полягає в тому, що:

1) тримання під вартою осіб на непідконтрольній уряду території є незаконним, але сьогодні відсутня можливість переведення засуджених із зазначених територій на підконтрольну Україні територію;

2) правовий статус засуджених на тимчасово окупованих територіях визначається тим, чи вирок вступив у законну силу до початку антитерористичної операції, чи такі особи були затримані та/або засуджені членами незаконних збройних формувань;

3) по суті, правовий статус осіб, які відбувають покарання на тимчасово окупованих територіях Донецької та Луганської областей, не врегульований взагалі, тому існують проблеми 3 поверненням таких осіб на підконтрольні території навіть після відбуття покарання.

Останнім виділеним нами елементом кримінально-виконавчої характеристики осіб, які відбувають покарання на тимчасово окупованих територіях Донецької та Луганської областей, $\epsilon$ 
можливість реалізації прав і свобод особами, які відбувають покарання на тимчасово окупованих територіях Донецької та Луганської областей.

Дане питання вже неодноразово розкривалось нами в даній роботі. Сьогодні існує низка свідчень того, яким чином порушуються права осіб, які відбувають покарання на тимчасово окупованих територіях Донецької та Луганської областей. Серед наведених прикладів - залучення ув'язнених до участі в незаконних збройних формуваннях та проблеми із забезпеченням таких установ життєво необхідними ресурсами. Наприклад, вказується, що підвезення продовольства до більшості установ виконання покарань та слідчих ізоляторів у Донецькій та Луганській областях було ускладнено й стало небезпечним для життя постачальників [9]. Відповідно, самі бойовики таке постачання не здійснюють у необхідних обсягах, тому дана проблема залишається актуальною і до сьогодні. Також безумовно проблемним питанням $є$ складність переведення засуджених до установ відбування покарань, розташованих на підконтрольній Україні території. Так, станом на травень 2017 року вже 735 в'язнів подали заяви до офісу Омбудсмена України із проханням про переведення на контрольовану урядом України територію. Але при цьому варто урахувати, що в період з 2015 року до 2017 року лише 147 ув'язнених було переведено з території, що контролюється терористичними організаціями на територію України [10, с. 29]. Разом із тим дана ситуація останнім часом покращилась. Зокрема, 24.07.2019 року 64 в’язнів із самопроголошеної «Луганської народної республіки» було повернуто на підконтрольну територію. При цьому це вже було шосте переведення засуджених із окупованої території Луганської області. Загалом, починаючи від грудня 2018 року на підконтрольну Україні територію повернулись 319 засуджених [11]. Тобто, з одного боку, існує тенденція до покращення ситуації в даному аспекті, із іншого, як свідчать статистичні дані, станом на сьогодні не були переведені навіть усі засуджені із числа тих, які виявили таке бажання. У той самий час очевидно, що на підконтрольну Україні територію мають повернутись усі ув'язнені, адже наша держава лише в такий спосіб зможе гарантувати дотримання їхніх прав, а також збереження життя в умовах ведення війни.

Загалом, проблеми реалізації прав і свобод особами, які відбувають покарання на тимчасово окупованих територіях Донецької та Луганської областей, є питанням, яке потребує окремого дослідження. Тому в контексті кримінально-виконавчої характеристики осіб, які відбувають покарання на тимчасово окупованих територіях Донецької та Луганської областей, зробимо висновок, що можливості реалізації прав і свобод особами, які відбувають покарання на тимчасово окупованих територіях Донецької та Луганської областей, $є$ обмеженими через таку специфіку:

1) засуджені поза їх волею залучаються до участі в незаконних збройних формуваннях;

2) засуджені не забезпечуються належним чином ресурсами, необхідними для їхнього існування;

3) переведення засуджених до установ відбування покарань, розташованих на підконтрольній Україні території, є ускладненим.

Висновки. Загалом, здійснене дослідження засвідчило, що кримінально-виконавча характеристика осіб, які відбувають покарання на тимчасово окупованих територіях Донецької та Луганської областей, відрізняється від кримінально-виконавчої характеристики будь-яких інших ув'язнених. У вітчизняній науці сформовано стабільні підходи до розуміння сутності кримінально-виконавчої характеристики особи, а також до того, які елементи ії складають. Утім, у контексті осіб, які відбувають покарання на тимчасово окупованих територіях Донецької та Луганської областей, варто враховувати зовсім інші критерії.

Передусім, такі особи є безпосередньо залежними від умов, в яких вони відбувають покарання, а також тих умов, які забезпечує окупаційна адміністрація установ виконання покарань на непідконтрольних територіях. Із даного приводу варто зробити висновок про те, що ув'язнені перебувають у важких умовах, а їхні права порушуються в різноманітні способи. Наступним виділеним нами елементом характеристики є правовий статус таких осіб. Специфіка правового статусу ув'язнених на тимчасово окупованих територіях Донецької та Луганської областей зумовлена тим, що він $\epsilon$ неоднорідним для осіб, які перебувають в ув'язненні. Критерії, за якими їхній правовий статус відрізняється, пов'язані з тим, чи була особа засуджена до 2014 року чи після, і яким був її правовий статус на момент початку війни. Останнім виділеним нами критерієм кримінально-виконавчої характеристики осіб, які відбувають покарання на тимчасово окупованих територіях Донецької та Луганської областей, $є$ гарантії реалізації такими засудженими своїх прав. Як нами встановлено, права засуджених на окупованих територіях регулярно порушуються в різноманітні способи, і кожне з таких порушень є елементом характеристики засуджених осіб. 


\section{Список використаних джерел:}

1.Богатирьов I.Г. Корекція поведінки засуджених жінок в установах виконання покарань. Чернігів, 2003. 168 с.

2.Лобжина Т.К. Права жінок, засуджених до позбавлення волі. Зб. наук. праць / Ред. кол.: Ю.В. Баулін (голов. ред.) та ін. Харків, 2007. Вип. 14. С. 144-153.

3.Бурда С.Я. Зміст кримінально-виконавчої характеристики засуджених до позбавлення волі. Науковий вісник Львівського державного університету внутрішніх справ. Серія юридична. 2011. Випуск 3. С. 213-221.

4.Царюк С.В. Кримінально-виконавча характеристика засудених, які відбувають покарання у виправних колоніях максимального рівня безпеки [Текст] : автореф. дис... канд. юрид. наук: 12.00.08 / Дніпропетровський держ. ун-т внутрішніх справ. Дніпро, 2009. 20 с.

5.Права позбавлених волі, які утримуються під вартою в ОРДЛО / упоряд. Є.Ю. Захаров, Н.М. Мельник. Харків : ТОВ «Видавництво «Права людини», 2018. 80 с.

6. Доклад о ситуации с правами человека в Украине 16 февраля - 15 мая 2017 г. : Управление Верховного комиссара Организации Объединенных Наций по правам человека [неофиц. перевод]. 54 с. URL : https://www.ohchr.org/Documents/Countries/UA/UAReport18th_RU.pdf (дата звернення: 21.07.2019).

7.Дотримання прав ув’язнених в Україні-2015. Доповідь «Донецького Меморіалу» / упоряд. О.П. Букалов. Харків, 2016. 48 с.

8.Россияне на оккупированном Донбассе «третируються» на зеках: веб-портал «News.online.ua». URL : https://news.online.ua/754602/rossiyane-na-okkupirovannom-donbassetreniruyutsya-na-zekah/ (дата звернення: 21.07.2019).

9.Дотримання прав ув'язнених в Україні-2014. Доповідь «Донецького Меморіалу» / упоряд. О.П. Букалов. URL : http://ukrprison.org.ua/publication/1430856171.

10. Правове свавілля в ОРДЛО. Звіт за результатами документування фактів порушень прав людини в окремих районах Донецької та Луганської областей. Київ, 2017 р. 56 с.

11. 3 окупованих територій повернули ще 64 в'язнів: веб-ресурс «5 канал». URL : https:// www.5.ua/suspilstvo/z-okupovanykh-terytorii-povernuly-shche-64-viazniv-podrobytsi-196279.html (дата звернення: 24.07.2019).

УДК 343.8

DOI https://doi.org/10.32844/2618-1258.2019.3-2.21

КОЛБ І.О.

\section{ПРО ЗМІСТ ТА ХАРАКТЕРИСТИКУ СИСТЕМОУТВОРЮЮЧИХ ОЗНАК ПОНЯТТЯ «ЗАХОДИ ВГАМУВАННЯ, ЩО ЗАСТОСОВУЮТЬСЯ ДО ЗАСУДЖЕНИХ У МІЦЯХ ПОЗБАВЛЕННЯ ВОЛІ УКРАЇНИ»}

У статті сформульовано авторський варіант поняття «заходи вгамування, що застосовуються до засуджених у місцях позбавлення волі України», а також здійснено аналіз його системоутворюючих ознак з урахуванням існуючих теоретичних та практичних проблем та запропоновані науково обгрунтовані заходи, спрямовані на удосконалення правового механізму з цих питань. Наголошено, що під насильством, що не $\epsilon$ небезпечним для життя чи здоров'я потерпілого, розуміється умисне заподіяння легкого тілесного ушкодження, що не спричинило короткочасного розладу здоров'я або незначної втрати працездатності, а також вчинення інших насильницьких дій (завдання удару, побоїв, незаконне позбавлення волі) за умови, що вони не були небезпечними для життя чи здоров'я в момент заподіяння.

3'ясовано, що в юридичній літературі, зокрема при кваліфікації злочинів проти власності, під психічним насильством розуміють будь-яку погрозу, яка спрямована

(C) КОЛБ І.О. - кандидат юридичних наук, начальник відділу нагляду за додержанням законів при виконанні судових рішень у кримінальних провадженнях та інших заходів примусового характеру (Прокуратура Київської області) 